\title{
İnsan Kaynakları Yöneticilerinin Gözünden Çeşitlilik, Kapsayıcılık ve Dışlayıcılık
}

\section{Duygu ACAR ERDUR}

\begin{tabular}{ccc}
\hline \multicolumn{1}{c}{ Geliş Tarihi/ Received } & Kabul Tarihi/ Accepted & Yayın Tarihi/ Published \\
$28 / 02 / 2019$ & $12 / 12 / 2019$ & $25 / 01 / 2020$ \\
\hline Citation/Atıf: Acar Erdur & D., (2020), İnsan Kaynakları Yöneticilerinin Gözünden Çeşitlilik, \\
Kapsayıcılık ve Dişlayıcılık, Atatürk Üniversitesi İktisadi ve İdari Bilimler Dergisi, 34(1): 214-234, \\
DOI: 10.16951/atauniiibd.533553
\end{tabular}

Öz: Bu çalışmada, son dönemde uygulamacılar ve akademisyenler tarafından oldukça ilgi gören bir insan kaynakları pratiği olan çeşitlilik yönetimine temel teşkil eden çeşitlilik, kapsayıcılık, dışlayıcılık gibi kavramların Türkiye bağlamında insan kaynakları yöneticileri tarafından nasıl anlamlandırıldığ 1 araştırılmıştır. Bu kapsamda araştırmada, çeşitlilik dendiğinde hangi boyutların algılandığı, hangi boyutların kapsayıcılık temelinde ele alındığ 1 , hangilerinin kapsam dışı bırakıldığı ve bu tercihin arkasındaki nedenlerin neler olduğu tespit edilmeye çalışılmıştır. Araştırmanın örneklemi 38 insan kaynakları yöneticisinden oluşmaktadır. Açık uçlu sorulara verilen yanıtlar çeşitlilik olarak algılanan boyutların etnik köken, dini yönelim ve siyasi yönelim olduğunu göstermektedir. Bu boyutlar aynı zamanda çeşitlilik yönetimi ve kapsayıcılık temelinde değerlendirilmeyen ve dışlanan boyutlar da olarak dile getirilmektedir. Bulgular, toplumsal, kültürel ve siyasi yüklerin çeșitlilik ile ilgili kavramsallaştırmaları biçimlediğini, kapsayıcı ve dışlayıcı uygulamalara çerçeve çizdiğini göstermektedir.

Anahtar Kelimeler: çeşitlilik, çeşitlilik yönetimi, kapsayıcılık, dışlayıcılık, insan kaynakları yönetimi

Diversity, Inclusion and Exclusion in the Eyes of Human Resources Managers

Abstract: In this study, how diversity, inclusion and exclusion are given the meaning by human resource managers in the Turkish context are investigated as the basic concepts of a human resource practice, diversity management which received significant interest by practitioners and academics in the recent years. In this context, it is tried to determine the dimensions that are perceived by human resource managers, the dimensions that are handled on the basis of inclusion, the dimensions that are exposed to exclusion and the reasons behind this preference. The sample of the study consists of 38 human resources managers. The answers to open-ended questions show that the most mentioned diversity dimensions are ethnic origin, religious and political orientation. These dimensions are also expressed as excluded dimensions that are not handled on the basis of diversity management and inclusion. The findings show that social, cultural and political burdens shape the conceptualizations of diversity and draw a framework for inclusive and exclusive practices.

Keywords: diversity, diversity management, inclusion, exclusion, human resource management

${ }^{1}$ Dr.Öğr.Üyesi, Beykent Üniversitesi, İktisadi ve İdari Bilimler Fakültesi, İşletme Bölümü, https://orcid.org/0000-0002-4288-4401 
İnsan Kaynakları Yöneticilerinin Gözünden Çeşitlilik, Kapsayıcılık ve Dışlayıcılık

\section{EXTENDED ABSTRACT}

\section{Research Problem}

This study focus on the perceptions of human resource managers about the diversity, inclusion and exclusion in the Turkish context. As diversity and diversity management received significant interest from practitioners and academics in the recent years, the study questions the universality of the conceptualizations of these fundamental concepts.

\section{Research Questions}

In this study, three research questions are addressed. Firstly, the study aims to understand "how Turkish human resource managers perceive diversity?" Moreover, it tries to understand "which diversity dimensions are handled on the basis of inclusion through human resource practices and why?" Besides, the study aims to reveal the diversity dimensions that are exposed to exclusion and the reasons behind this preference.

\section{Conceptual Framework}

The conceptual framework of the study is based on the debate on diversity which is heated after the emergence of diversity management that emerged in the 1980s in the United States of America. US-based mainstream research emphasizes the benefits of diversity and tends to regard diversity management as a universal practice. However, especially with the European-based studies, the universality of diversity management the logic of the practice have started to be questioned. The diversity concept evolved to 'diversity and inclusion'. Thus, inclusive organizational practices and exclusion are started to be discussed in the literature. Based on these debates, this study tries to demonstrate the conceptualizations of HR managers about diversity, inclusion and exclusion in the Turkish context which reflects a different institutional setting from the US and Europe.

\section{Methodology}

This study tries to find answers to how and why questions related to the diversity perception in the eye of Turkish human resource managers. Thus, in line with the research questions, qualitative methodology is followed. The sample of the study consists of human resources managers which are the members of People Management Association of Turkey (PERYÖN) and Association of Supporting Diversity in Knowledge and Practice (BUÇAD). A question form consisting of openended questions was designed to reveal the meanings ascribed to diversity, inclusion and exclusion by HR managers. This question form was sent to the members via BUÇAD and PERYÖN Bursa and İstanbul Central branches which is responded by 32 HR managers. Also a focused group interview was conducted by 6 members of BUÇAD. The qualitative data is analyzed by descriptive analysis.

\section{Results and Conclusions}

The findings show that the most mentioned diversity dimensions by HR managers for the Turkish context are ethnic origin, religion and political orientation. However, these dimensions are not considered in diversity management practices or in the inclusion oriented programs. Even, these diversity dimensions are expressed 
as the excluded dimensions. The findings show that socio-cultural and religious structure of a country have an influence on the diversity conceptualization, which leads to the ignorance of various diversity dimensions. Moreover, macro political context shapes the discourse of human resource managers' discourse and human resource practices in the organizations. Additionally, the organizational cultural norms also have effect on the perception on the diverse identities. Consequently, the findings demonstrate that social, religious, cultural, and political structures and burdens shape the conceptualizations of diversity and draw a framework for inclusion and exclusion oriented practices. In other words, the "norm" determines the diverse and excluded.

\section{I.Giriş}

Bu çalışma, 1980'li yıllarda Amerika Birleşik Devletleri(ABD)'nde ortaya çıkmış olan çeşitlilik yönetimi (Wrench, 2007) pek çok yönetim pratiği gibi kısa sürede popülerlik kazanarak farklı ülkelere yayılım sağlamıştır. (ör. Boxenbaum,2006; Ferner, 2005; Heres ve Benshop, 2010; Jack ve Lorbiecki, 2007; Omanovic, 2009;Risberg ve Soderberg 2008; Sippola ve Smale, 2007). Ancak çeşitlilik yönetimi uygulamalarının, ABD'de ortaya çıkmış olması ve baskın olarak ABD'nin demografik, politik, ekonomik ve sosyo-kültürel yapısından izler taşıyan bir yönetim uygulaması olması nedeniyle ABD'ye içkin olduğu kabul edilmektedir. (Omonovic, 2009; Zanoni vd. 2010) Bu noktada, ABD'ye özgü olan bir pratiğin, ABD'de kavramsallaştırıldığı ve uygulandığı şekliyle ABD dışındaki ülkelerde ne derece benimseneceği tartışmalı bir konu olarak kabul edilmektedir (Ferner vd., 2005, Risberg, ve Soderberg, 2008). Her bağlamda çeşitlilikten anlaşılan şeyin değişmesi; farklı şekilde algılanıp farklı şekilde anlamlandırılması, buna bağlı olarak ele alınan çeşitlilik boyutlarının ve ele alınma biçimlerinin de farklılaşması beklenebilir. Öyle ki, farklı bağlamlarda içinde barındığı politik, sosyal ve kültürel yükler nedeniyle "çeşitlilik/farklılık" olarak adlandırılan grupların değişmesi; bazı grupların öne çıkarılırken, bazılarının göz ardı edilmesi ve dolayısıyla ele alınan çeşitlilik boyutlarının ve ele alınma biçimlerinin de farklılaşması beklenebilir.

Öte yandan, çeşitlilik yönetimini ABD bağlamında gündeme getiren ve işletmeleri bu uygulamaya yönelten dinamiklerin, diğer ülkeler ile farklılık göstermesi de söz konusudur. ABD bağlamında çeşitlilik yönetimi uygulamalarının yayılımı daha çok "stratejik avantaj yaratma, yaratıcılık ve yenilikçiliğe katkı, nitelikli insan kaynağını çekme" vb. etkinlik temelli söylem üzerinden gerçekleşmektedir. (Kelly ve Dobbin, 1998). Ancak ABD dışındaki ülkelerde, işgücü piyasasının niteliği ve işletmelerin etkinlik beklentilerinin insan kaynağı çeşitliliği ile ilişkisinin de farklı olması mümkündür. Her ülkede nitelikli, işletmeye değer katacak ancak farklı kabul edildiği için işletme yapısı içinde yer bulamayan veya çeşitlilik yönetimi/kapsayıcılık uygulamaları olmadığı için "kaybedilen" bir insan kaynağı profilinden söz etmek güçtür. Türkiye'de de aynı biçimde işgücü piyasasının nicelik ve niteliğinin kendine özgü koşullar yaratacağını beklemek, bu 
İnsan Kaynakları Yöneticilerinin Gözünden Çeşitlilik, Kapsayıcılık ve Dışlayıcılık

koşulların işletmelere çeşitlilik yönetimi üzerinden bir stratejik avantaj kazandıracak zemine sahip olup olmadığını tartışmak mümkün görünmektedir.

İlgili literatürde; örgütsel değişim gerektiren uygulamaların, ortaya çıktıkları mekânın problemlerinden bağımsız olarak ele alınmasının ve seyahat ettikleri ülkede aynı şekilde benimsenmesini ve uygulanmasını beklemenin doğru olmayacağ 1 vurgulanmaktadır (Sahlin-Andersson,1996:71). Buradan hareketle, ortaya çıkış1 itibariyle ABD'ye özgü kabul edilen çeşitlik yönetimi pratiğinin ve bu pratiğe temel teşkil eden kavramların seyahat ettikleri bağlamlarda yeniden kurgulanmalarını beklemek mümkündür. (Boxenbaum, 2006; Meriläinen vd, 2009; Barbosa ve Cabral-Cardoso, 2010).

Özellikle Türkiye gibi farkl11ıklar konusunda hassas kabul edilen bir ülkede, çeşitlilik ve kapsayıcılık kavramlarının nasıl tanımlandığı, çeşitlilik dendiğinde hangi boyutların algılandığı, hangi boyutların çeşitlilik yönetimi ve kapsayıcılık temelinde değerlendirildiği, hangilerinin kapsam dışı bırakıldığı ve bu tercihin arkasındaki nedenlerin neler olduğu tartışmaya açıktır. Bu çalışmada söz konusu pratiğe temel teşkil eden çeşitlilik, çeşitlilik yönetimi, kapsayıcılık ve dışlayıcılık kavramlarının Türkiye bağlamında insan kaynakları (İK) yöneticileri tarafından nasıl anlamlandırıldığını ortaya çıkarılması amaçlanmaktadır. Bununla birlikte, IK yöneticilerinin Türk iş yaşamında en çok dışlanan gruplara ilişkin algıları ile bu dışlamanın arka planındaki nedenler tespit edilmeye çalışılmaktadır. Böylece, bu çalışmanın, bir İK pratiğine temel teşkil eden kavramların yerel bağlamda nasıl anlamlandırıldığına, içeriğinin nasıl (yeniden) inşa edildiğine ve bu kurgulama sürecinde nelerin etkili olduğuna ilişkin bir anlayış geliştirilmesine katkı sağlaması umulmaktadir.

\section{Kavramsal Çerçeve}

Çeşitlilik yönetimi 1980'li yıllarda ABD'de ortaya çıkmış bir İK pratiğidir (Wrench, 2007, s.13). Genel olarak, "işgücü farklılıklarını anlamak ve bu farklılığ1 bireylerin ve örgütlerin yararına yönetmek amacıyla doğru sistemler kurmak" olarak tanımlanan çeşitlilik yönetimi, çeşitlilik arz eden işgücünün örgüte çekilmesi, bu işgücünün potansiyelinin ortaya çıkarılması, bu potansiyeli kullanarak örgütün performansının arttırılması ve böylece rekabet avantajı elde edilmesini amaçlayan bir anlayışı yansıtmaktadır (Kelly ve Dobbin, 1998; Thomas, 1990; Cox ve Blake, 1991). Çeşitlilik yönetimi kapsamında, yasal olarak ayrımcılık yapmamanın ötesinde çeşitlilik; yeni pazarlara giriş imkanı, yaratıcılık, problem çözme ve esneklik kazanma gibi pragmatik argümanlarla ilişkilendirilmektedir (Cox ve Blake, 1991; Thomas, 1990). Burada sözü edilen çeşitlilik, birincil boyutlar olarak kabul edilen, ırk, etnik köken, cinsiyet, yaş, engellilik durumu, cinsel yönelim ile ikincil boyutlar olarak kabul edilen; din, dil, ailevi durum, gelir düzeyi, iletişim ve çalışma tarzı, deneyim gibi boyutlar üzerinden ele alınmaktadır (Milliken ve Martins, 1996).

Çeşitlilik yönetimi uygulamalarının temelinde ABD'de 1950-1960'larda yaşanan liberal hareketler ve sivil hakları eylemler olduğu bilinmektedir. Bu süreçte, siyah-beyaz ayrımcılığ başta olmak üzere her türden ayrımcılığa karşı yürütülen adil 
istihdam ve olumlu eylem/pozitif ayrımcılık gibi programların çeşitlilik yönetimi uygulamalarının ortaya çıkmasına bir zemin oluşturduğu kabul edilmektedir (Kelly ve Dobbin, 1998:974-975). Bununla birlikte, 1987 ve 2000 yıllarında Hudson Enstitüsü tarafından yayınlanan Workforce 2000 ve Workforce 2020 raporlarında, ABD'deki nüfusun hızla çeşitlenmekte olduğunu ve bu çeşitliliğin ABD ekonomisi için bir "etkinlik problemi" olarak konumlandırılması gerektiği ortaya konmuştur (Johnston ve Packer, 1987:51-57). Kriz benzeri bir yaklaşımla iş dünyasını değişen işgücü profiline karşı hazırlıklı olma konusunda uyaran bu raporların yayınlanması "çeşitliliği yönetme" söylemini güçlendirmiştir (Cox ve Blake, 1991; Kelly ve Dobbin, 1998; Thomas, 1990;1991). Öyle ki, etnik köken, ırk ve kültür açısından büyük bir çeşitliliğe sahip olması, bu uygulamaların ABD için bir zorunluluk olarak kabul edilmesine neden olmuştur (Ivancevich ve Gilberth, 2000:76). Bu noktada, ortaya çıkış sürecindeki demografik, sosyolojik, politik ve ekonomik etkiler değerlendirildiğinde çeşitlilik yönetiminin ABD'ye içkin bir uygulama olduğunu söylemek mümkün görünmektedir.

Bununla birlikte çeşitlilik yönetimi, kısa sürede popülerlik kazanarak diğer ülkelere-özellikle Avrupa'ya (İngiltere, (Ferner, 2005; Jack ve Lorbiecki, 2007; Lorbiecki ve Jack, 2000); Hollanda (Boxenbaum,2006; Heres ve Benshop, 2010; Finlandiya, Sippola ve Smale, 2007); Danimarka, (Risberg ve Soderberg 2008); İsveç, (Omanovic, 2009); Fransa, (Klarsfeld, 2009); Belçika (Janssens \& Zanoni, 2005)'ya yayılım sağlamıştır. Bu çalışmalar, çeşitlilik yönetimin bağlama duyarlı olduğunu göstermiştir. Her ne kadar ABD'ye içkin çeşitliliği yönetme anlayışı bu ülkelerdeki söylemi kısmen etkilemiş olsa da çeşitlilik yönetimi ABD dışına seyahatinde yeniden yorumlanarak, fikir ve uygulamada belirli ölçüde farklılaşmıştır (Omanovic, 2009, 354). Bu farklılaşma, çeşitlilik yönetiminin evrensel olduğu kabulünü reddeden bir anlayışa işaret etmektedir.

Pek çok çalışmada vurgulandığı üzere; çeşitlilik yönetimi, ABD’nin demografik, politik, sosyokültürel ve ekonomik gerçekleri ile şekillenmiş bir yönetim pratiğidir. $\mathrm{Bu}$ nedenle seyahat ettiği ülkelerin makro bağlamlarındaki demografik, sosyo-kültürel, politik ve ekonomik faktörlerin ABD'dekinden farklı etkilerinin olması, her ülkede ön planda olan farklılık boyutlarının değişkenlik göstermesine neden olurken, bu uygulamalara yüklenen anlamları ve uygulanma şekillerini de biçimleyebilmektedir (Nishii ve Özbilgin, 2007; Syed ve Özbilgin,2009). Örneğin Boxenbaum (2006), çeşitlilik yönetiminin ABD’den

farklı olarak Danimarka'da içinde demokrasi ve bireysel gelişim öğeleri olan ve sosyal sorumluluk anlayışından izler taşıyan şekilde yeniden kurgulandığını tespit etmiştir. Benzer şekilde, Hollanda'da da çeşitlilik söylemi sosyal sorumluluk ve eşitlik vurgusu taşımaktadır (Heres ve Benchop,2010). Bu açıdan özellikle Avrupa temelli çalışmalar ABD dışında çeşitliliğin daha çok moral ve etik bir şekilde ele alındığını ve ilgili söylemin "çeşitliliği yönetme" anlayışından "her türlü çeşitliliği kapsayıcı bir örgüt yaratma" anlayışına dönüştügünü göstermektedir (Oswick ve Noon, 2014,s.25-26). Diğer bir deyişle, çeşitlilik yönetimi pratiğinin ABD'den Avrupa ülkelerine seyahatine ilişkin akademik çalışmalara bakıldığında ilk olarak 
İnsan Kaynakları Yöneticilerinin Gözünden Çeşitlilik, Kapsayıcılık ve Dışlayıcılık

ortaya çıkan görünüm, çeşitlilik yönetimi pratiğinin kapsayıcılık kavramına doğru dönüşümüne işaret etmektedir. $\mathrm{Bu}$ durum, temelli bir yorum farkını ortaya koymaktadır.

Örgütler açısından kapsayıcılık, tüm bireysel farklılıkların kabul edilmesi ve tüm çalışanlara aynı şekilde muamele gösterilmesini sağlayacak bir örgütsel iklim yaratılması olarak tanımlanmaktadır (Janssens ve Zanoni, 2008; Roberson, 2006). Ferdman, (2017, s.238) kapsayıcılığ1; "bireylerin, onları kendileri yapan kimliklerini ve bireysel benzersizliklerini bırakmalarına gerek kalmadan bütüne tam olarak katılım ve katkı sağlayabilmeleri" olarak tanımlamaktadır. Daha açık bir ifade ile, kapsayıcılık, toplumsal olarak "marjinal" kabul edilen ve ayrımcılığa uğrayan grupların üyelerine, özgün olarak kendileri olmaları desteklenerek örgütün tüm süreçlerine katılma ve katkıda bulunmalarına imkan veren örgütsel ortamı yaratmak şeklinde tarif edilmektedir (Ferdman, 2014; Bell, Özbilgin, Beauregard, \& Sürgevil, 2011; Shore vd., 2018). Bu açıdan kapsayıcılık, çeşitliliğe rekabet aracı olarak konumlandırmaksızın değer atfetmesi sebebiyle çeşitlilik yönetiminden ayrılmaktadır(Roberson, 2006). Yani kapsayıc1lık, işletme temelinde ve etkinlik arayışına dayalı pragmatik gerekçelerle değil, ulusal hatta uluslararası düzeyde, insan hakları ve evrensel çalışma hakları vurgusuna daha yakın bir söylemle ele alınmaktadır. Bu durum, çok genel bir çerçevede, ABD ve Avrupa arasındaki kurumsal bağlam farklılıklarının bir yansıması olarak yorumlanabilir.

Son dönem literatür incelendiğinde örgütlerin nasıl daha kapsayıcı hale gelebileceklerini tartışan çalışmaları görmek mümkündür (ör. Ferdman,2014; Nishi, 2014; Shore, vd., 2018). Örneğin Ferdman (2014), kapsayıcılık literatürünün tematik bir tasvirini yaptığı çalışmasında, örgüt içinde kapsayıcılığın deneyimlenebilmesi için alt1 temel unsurdan bahsetmektedir. Bunlar; güvende hissetme, iş gruplarına dâhil olma, saygl görme ve değerli hissetme, karar alma süreçlerine katkl verebilme, görünürlük (kendini olduğu gibi ortaya koyabilme) ve çeşitliliğin tanınması, onurlandırılması ve gelişmesi olarak açıklanmaktadır.

Ancak, kapsayıcı uygulamaların tasarlanması (Offerman ve Basford, 2014; Tang vd.,2015) ve kapsayıcı iklim yaratılması adına gerçekleştirilen çabalara (Downey, vd.,2015; Nishii and Rich, 2014) rağmen tam anlamıyla kapsayıcı bir örgüt yaratmanın zor olduğu; kapsayıcıllğın çeşitli çatışmaları ve ikilemleri barındırdığı vurgulanmaktadır. Öyle ki, hangi bağlamda, hangi aktörler tarafından ve hangi amaçla tanımlandığı kapsayıcılığın nasıl şekillendiği konusunda belirleyicidir (Ferdman, 2017:239). Örneğin, farklı etnik gruplara ilişkin kapsayıc1 uygulamaları teşvik etmek, engelli bireyler için gerçekleştirilecek uygulamalardan söz konusu çeşitlilik boyutlarının doğası gereği farklı odaklanmaları gerektirebilecektir (Ferdman, 2017:40). Hatta toplumsal düzeyde, tarihsel süreç içinde belirli gruplar arasındaki güç mücadelelerine ilişkin gerginlikleri dahi su yüzüne çıkarabilecektir (Ferdman, 2017:258). Dışlayıc1lığın var olduğu örgüt ise tüm çalışanlarının "o örgütün ana akımı" tarafından belirlenmiş normlara uygun olması gerektiği algısının var olduğu bir örgütü ifade etmektedir (Mor Barak ve Daya, 2014:393-394). Bu noktada, Mor Barak (2015:84) tarafindan yapılan 
"çeşitlilik, bireyler arasındaki antropolojik farklılıklardan çok toplumda ana akım olarak kabul edilenlerden farklı olan gruplara ait olmak ile ilgilidir" şeklindeki çözümlemenin dışlayıcı tutuma bir çerçeve çizdiği söylenebilir.

Yukarıdaki teorik çerçeveden hareketle, Türkiye'de, hem ABD hem de Avrupa ülkelerinden farklı gelişen iktisadi, sosyal, politik süreçlerin, gelişmişlik düzeyinin, inanç sisteminin çeşitlilik/kapsayıcılık/dışlayıcılık kavramlarına yansıması beklenmektedir. Farklılıkların dile getirilmesi, bunların iş ortamına yansitılması ve yönetilmesi, söylenmesi mümkün olan ve olmayan, kabul edilebilir olan ve olmayan farklılık anlayışı ile beraber, çeşitliliklerin yönetimi uygulaması meşruiyet krizini de doğurmaktadır. Meşruiyet sorunsalı olan bir pratiğin uygulamada hangi süreçlerden geçtiği, nasıl bir yol aldığı ve nihai olarak "neye dönüştüğü” bu çalışmanın temel sorunsalını oluşturmaktadır.

Özetle bu çalışmada, Türkiye bağlamında, çeşitlilik, kapsayıcılık ve dışlayıcılıktan ne anlaşıldığına, çeşitlilik ve kapsayıcılığa ilişkin söylemin ne şekilde (yeniden) inşa edildiğine ve bu süreçte hangi saiklerin belirleyici olduğuna ilişkin bir anlayış geliştirmek amaçlanmaktadır.

\section{III.Araştırma Tasarımı}

Çeşitlilik yönetimi üzerinden bir yönetim uygulamasına temel teşkil eden kavramların yerel bağlamda "nasıl" anlamlandırıldığını araştıran bu çalışmada, araştırma sorusu ile uyumlu olarak; bir durumu kendi bağlamında ele alarak derinlemesine tanımlama ve yorumlama imkânı veren nitel araştırma metodolojisinden yararlanılmıştır. Bilindiği gibi, nitel araştırma, gerçekliğin; birbirleriyle etkileşimde bulunan sosyal aktörlerin eylemleri ile yaratıldığını, zamana ve kültüre bağlı olarak sürekli değiştiğini yani durağan, düzenli ve evrensel olmadığ 1 kabulüne dayanmaktadır(Yıldırım\&Şimşek,2000:30). Bu noktada gerçekliğin ne olduğu, bireylerin onu nasıl deneyimlediklerine, nasıl tanımladıklarına ve nasıl anlamlandırdıklarına bağlı olacak şekilde sosyal olarak inşa edilmektedir(Kuş,2003:65). Dolayısıyla, anlamacı epistemolojiye dayanan nitel araştırmalar, evrensel yasalar bulmak yerine, belirli koşullar altında bir olguya açıklama getirmeye ve anlamaya çalışmaktadır. Buradan hareketle, bu çalışmanın araştırma sorusu gereği yöntem olarak nitel araştırmanın tercih edilmesinin uygun olacağı düşünülmüsşür.

Çalışmanın örneklemini (Bilgide ve Uygulamada Çeşitliliği Destekleme Derneği (BUÇAD) ve Türkiye İnsan Yönetimi Derneği (PERYÖN) üyesi İK yöneticileri oluşturmaktadır. İK yöneticilerinin tercih edilmesinin nedeni ise çeşitlilik yönetiminin bir İK pratiği olarak konumlandırılmasıdır. Araştırma kapsamında, İK yöneticilerinin, çeşitlilik, çeşitlilik yönetimi ve kapsayıcılık/dışlayıcılık kavramlarına yükledikleri anlamların ortaya çıkarılmasına imkân verecek şekilde açık uçlu sorulardan oluşan bir soru formu tasarlanmıştır. Bu soru formunda "sizce Türk toplumunda ne tür çeşitlilikler/farkl1lıklar var?" , "çeşitlilik yönetimi dendiğinde ne anlıyorsunuz?", "sizce, bir işletmede çeşitliliğin yönetilmesi ne demektir?", "kapsayıcılık dendiğinde ne anlıyorsunuz?" gibi sorular 
İnsan Kaynakları Yöneticilerinin Gözünden Çeşitlilik, Kapsayıcılık ve Dışlayıcılık

yer almaktadır. Bu soru soru formu, BUÇAD ve PERYÖN Bursa ve İstanbul Merkez şubeleri aracılığıyla üyelere ulaştırılmıştır. Söz konusu soru formuna 32 İK yöneticisinden cevap gelmiştir. Formun teknik olarak ulaştığı kitle göz önüne alındığında katılım oranı düşüktür. Soru formu üzerinden derlenmeye çalışılan verilerin yanı sıra, BUÇAD'ın yönetim kurulu üyeleriyle toplam 6 kişi'den oluşan bir odak grup görüşmesi gerçekleştirilmiştir. Bu görüşmeye katılan yöneticilere, çeşitlilik kavramının tanımı, Türkiye'deki işgücü açısından hangi çeşitliliklerden/farklılıklardan söz edilebileceği, kapsayıcıllı̆̆ın ve dışlayıcılığın ne anlama geldiği, en çok dışlandığını düşündükleri grupların hangileri olduğuna, ilişsin sorular yöneltilmiştir. Bununla birlikte, sorulara verilen cevaplardan, tüm bu kavramsallaştırmaların arka planına ilişkin bir çözümleme yapılmaya çalışılmıştır. Araştırmada elde edilen veriler üzerinden betimsel analiz gerçekleştirilmiştir. $\mathrm{Bu}$ kapsamda öncelikle; araştırmanın kavramsal çerçevesi ve elde edilen verilerden yola çıkarak yapılan çıkarımlar açıklanmaya ve teorik çerçeve ile ilişkilendirilmeye çalışılmıştır. Elbette, bu araştırmadan elde edilen verilen üzerinden yapılan yorumlar incelemeye tabi olan örmekler ile sinırlıdır.

IV. Bulgular
Araştırma bulguları, ç̧̧⿻弋口ililik ve çeşitlilik yönetimine ilişkin kavramsallaştırmalar, kapsayıcılık ve dışlayıcılığa ilişkin kavramsallaştırmalar ve bu kavramsallaştırmaların arka planındaki nedenler olmak üzere üç başlık altında verilmeye çalışılacaktır. Bulgular, katılımcıların ham ifadelerini yansıtacak biçimde derlenerek sunulmaktadır. İfadelerin derlenmesinde, kavramlara ilişkin yansıtıcı (bağlamsal özgünlükleri vurgulayan) tanımlar ile en çok tekrar eden kavramları içeren ifadelerden örneklerin seçilmesi yoluna gidilmiştir. Araştırma amaçları doğrultusunda oluşturulan açı uçlu sorulara ait örnek cevaplar aşağıda yer almaktadır.

\section{A. Çeşitlilik ve Çeşitlilik Yönetimine İlişkin Kavramsallaştırmalar}

Katılımc1lara "Sizce Türk toplumunda ne tür farklıllklar/çeşitlilikler var?, Farklılaştı̆̆ını düşündüğ̈̈n̈̈z gruplar ya da topluluklar hangileridir?” şeklinde yöneltilen soruya verilen cevaplar içinde Türk toplumunun tarihsel arka planına vurgu yapılarak etnik köken, dil ve inanç boyutlarının ağırlıklı olarak dile getirildiği görülmüştür. Bu soruya verilen örnek cevaplar aşağıdaki gibidir;

"Türk toplumu tarihi boyunca farklılık gösteren birçok etnik köken, ayr inançta insanlar, ayrı dili konuşanları bir arada barındırmış olan büyük bir kültüre sahiptir. Buda iş ve çalışma hayatındaki farklılık ve çeşitlilik konusunda da etkisini göstermektedir."

"Türk toplumu, tarihinden süregelen çok çeşitli ulus yapısı sebebiyle her zaman etnik köken, inanç, dil konusunda çeşitliliğe sahiptir"

Etnik köken boyutu ile ilgili yapılan açıklamalar daha çok Türk/Kürt kimliğini örneklemektedir. Bir diğer kategori, inanç temelinde şekillenmektedir. Burada farklı 
dinlere vurgu yapılmazken, Türkiye'ye özgü biçimde Alevi/Sünni ayrımını dile getirilmektedir. Örneğin;

"Kürt, Türk; Alevi-Sünni gibi çeşitlilikle yapısını sürdürmeye devam etmiş bir topluluktur Türk toplumu"

Öte yandan, son dönemin siyasal söylemi, çeşitlilik kategorilerine de kısmen yansımış görünmektedir;

"3 ana eksen olduğunu düşünüyorum. 1- etnik (Kürt / Türk), 2- mezhep (Alevi /Sünni, 3- inanç (laik / dinci) bununla birlikte ayrımcllı olarak kadın lerkek konusunu da göz önüne almakta fayda bulunmaktadir."

"Aslında Türkiye'ye özgü etnik kökenler, kapalı olmak-olmamak, ya da ve buna karşı olanlar olmayanlar. Aslında siyasi görüş bile çeşitliliğin içinde saylmall."

Cinsiyet, kadın/erkek ayrımı biçimde ifade edilmektedir. Ayrıca kadınlara ilişkin olarak "evli/dul" ve "kapalı/açık" olma bir farklılık biçiminde ifade edilmiştir. Bir katılımcı bu durumu şu şekilde açıklamaktadır;

"Aile ile ilgili normlar evli/dul/çocuklu/çocuksuz, kadınların giyimine göre kapalı/açık, ekonomik durum, ekonomik durum, engellilik."

"Engelli, y kuşağl, çok çeşitti illerden gelen, Suriyeli, Ahıskall, Kürt, AKP sempatizanı, kapalı, açık, evli ve dul kadınlar."

$\mathrm{Bu}$ boyutların yanı sıra engellilik son dönemdeki kamuoyu söyleminde yer alma sıklığı ile birlikte düşünüldügünde, yöneticilerin gündeminde olan ve sıklıkla belirttikleri bir diğer boyuttur. Çeşitlilik boyutları arasında en az dile getirilen boyut cinsel yönelim boyutu olmuştur. Katılımcılar arasından sadece 3 kişi cinsel yönelimi dile getirmiş ve yalnızca 1 kişi "gey” kelimesini kullanmıştır. Örnek cevaplar aşağıda yer almaktadır;

"Bulgaristan göçmenleri, gey, Alevi-Sünni, Suriyeli, Gurbetçi, Kadın-erkek"

"İnanç, siyasi görüş, etnik köken, cinsel yönelim”

"Etnik köken, dini inançlar, siyasi yönelim, cinsel yönelim"

BUÇAD'ın çeşitlilik boyutları ile ilgili yaklaşımını ise yönetim kurulu üyelerinden birinin verdiği yanıttan izlemek mümkündür.

"Biz iş hayatında çeşitliliğin desteklenmesini amaç edinmiş bir derneğiz. Farklı din, dil, ırk, kültür, cinsiyet, engellilik boyutlarını daha çok ele alıyoruz. Bir tek cinsel yönelim boyutuna girmedik, dokunmak istemedik, biraz hassas bir konu olduğu için"

Bu cevaplar incelendiğinde, cinsel yönelim boyutunun söylemde ve pratikte çok fazla yer bulmadığı görülmektedir. İnsan kaynakları yöneticileri tarafından en az dile getirilen boyut olmakla birlikte, çeşitliliği destekleme motivasyonuna sahip bir derneğin cinsel yönelim boyutunu faaliyetlerine dahil etmemesi, bu boyutu hassas kabul ederek bu konuda herhangi bir inisiyatif almaması dikkat çekicidir.

Katılımcılara yönetilen "farklılık/çeşitlilik yönetimi dendiğinde ne anliyorsunuz? Sizce, bir işletmede çeşitliliğin yönetilmesi ne demektir?” sorusuna yabancı ortaklı ve tamamen yabancı sermayeye ait şirketlerde çeşitlilik yönetiminin 
İnsan Kaynakları Yöneticilerinin Gözünden Çeşitlilik, Kapsayıcılık ve Dışlayıcılık

ABD bağlamındakine benzer biçimde etkinlik vurgusu taşıyan pragmatik gerekçelere dayandırılarak tanımlandığı görülmektedir. Yabancı ortaklı bir işletmenin İK yöneticisi çeşitlilik yönetimini şu ifadelerle açıklamaktadır;

"İş yerinde çeşitliliğin kabul görmesi sadece temel insan haklarından kaynaklanan insanlar arası eşitlik ilkesi gereği değildir. Çeşitlilik doğru yönetildiğinde farklı bakış açıları, farklı deneyimler, farklı değerler işletmelere için yenilikçilik ve yaratıcılık perspektifi katabilir ve farklı müşteri gruplarına ulaşabilir."

Yerli sermayeye ait şirketlerin IK yöneticileri tarafından verilen cevapların önemli bir kısmında ise çeşitlilik yönetimi ilk sorudaki farklılık ya da çeşitlilik boyutlarını tekrar saymak biçimindedir. Örneğin;

"Yaş, dil, din, medeni durum, cinsiyet, etnik köken, sakatlık"

"Farklılık/Çeşitlilik yönetimi dendiğinde; yaşamın sürdüğü bir yerde mutlaka

farklı inanç gruplarından, kültürlerden, etnik kökenlerden, dillerden söz edilecektir."

"Her insan başlı başına zaten farklıdır; düşünce yapısı, yaşam tarzı, dili, dini, tercihleri gibi. Bu farklılıkların, çeşitliliklerin tek tarafl yönetilmesinin zor olduğu kanaatindeyim.'

$\mathrm{Bu}$ cevaplardan ulusal şirketlerin IK yöneticilerinin zihninde çeşitlilik yönetimine ilişkin net bir anlayışın var olmadığı ya da henüz oluşmadığı, çeşitlilik yönetimini bir IK pratiği ya da yönetim anlayışı olarak algılamadıkları yorumu yapılabilir. Bununla birlikte, yerel sermayeye ait 22 şirketin 3'ünde ise IK yöneticilerinin çeşitlilik yönetimini fursat eşitliği yaratmak ile ilişkilendirerek tanımladıkları görülmektedir. Örnek bir ifade aşağıda yer almaktadır;

"Tüm çalışanların görünen ve görünmeyen farklarına göre etiketlenmediği, sadece kendisi olarak değer bulduğu ve firsat eşitliği să̆landiğl bir ortam yaratılmast"

Yerel sermayeye ait şirketlerin Türkiye bağlamını yabancı ortaklı ya da tamamen yabanc1 sermayeli şirketlere kıyasla daha iyi yansitabileceği düşünüldüğünde, Türkiye'de çeşitlilik yönetimi kavramsallaştırmasının, ortaya çıttı̆̆ ABD bağlamındaki gibi çeşitlilikten avantaj elde etmek gibi pragmatik bir İK pratiği olarak konumlandırılmadığı ve kısmen de olsa fırsat eşitliği yaratılması ile ilişkilendirildiğini söylemek mümkün görünmektedir. Türkiye'deki tek çeşitliliği destekleme derneği olan BUÇAD'ın kuruluş motivasyonu da bu çıkarımı destekler niteliktedir;

"İş hayatında insanların görünen ya da görünmeyen farklllıklarından dolayı bir etiketle algılanmadı̆̆ ve herkesin firsat eşitliğine sahip olduğu şekilde bir çalışma ortamı hayaliyle başladık"

\section{B. Kapsayıcılık ve Dışlayıcılı̆̆a İlişkin Kavramsallaşstırmalar}

Literatürden izlendiği üzere çeşitlilik yönetimi pratiğinin kendi içindeki evrimi sonucunda kapsayıc1lık ile ilişkilendirilmektedir. Bu kapsamda katılımcılara "kapsayıcılık" kavramından ne anladıklarına ilişkin bir soru yöneltilmiştir. Bu 
soruya verilen cevaplarda, kapsayıcıllı̆ın genellikle örgüt içinde çeşitliliklerin kabul edilmesi ve bireyin kendi kimliğini saklama gereği duymaması şeklinde kavramsallaştırıldığ görülmektedir. Örneğin bir katılımcı kapsayıcılığı şu şekilde ifade etmiştir;

"Bireylerin kendi sahip oldukları özelliklerini rahatça ortaya koyup, paylaşabilecekleri bir ortam"

Bununla birlikte, kapsayıcılık ile ilgili kavramsallaştırmalarda ayrımcılık/dışlayıcılık yapmama, örgütsel adalet, kural ve prosedürlerde standartlaşma şeklindeki vurgu da ön plana çıkmıştır. Bu vurgu aşağıdaki örnek cevaplarda görülmektedir;

"Işsyeri ortamında saygl, eşitlik ve farklıllkların kabulü olarak ifade edebilirim. Örneğin, engelli birisinin diğer personellerden ayrı düşünülmeksizin davranılmasıdır. Yönetici pozisyonlarında değerlendirebilmesidir."

"IŞs yaşamında kapsayıcılık, tüm çalışanlar arasında oluşturulan işbirliği, karşıllklı destek ve karşılıklı saygı ortamı sayesinde çalışanların karar alma süreçlerine katılmaları, farklı fikirlerin kabul görüp, tartışılıp uygulanması, hiçbir görüş veya düşüncenin dışlanmadan kabul edildiği bir kurum kültürü unsurudur."

Yukarıdaki ifadeler değerlendirildiğinde, kapsayıcılık kavramının İK yöneticileri tarafından özüne oldukça yakın bir şekilde kavramsallaştırıldığı görülmektedir. Öyle ki bu soruya verilen cevaplar, literatürdeki hâkim kapsayıc1lık anlayışı ile paralellik göstermektedir. Yukarıda açıklandığı üzere, çeşitlilik ve kapsayıcılık ile ilişkili olan (Ferdman, 2017; Roberson, 2006) bir diğer kavram ise dışlayıcılıktır. Araştırma kapsamında, IKK yöneticilerinin dışlayıcılıktan ne anladığ 1 da tespit edilmeye çalışılmıştır. Verilen cevaplarda dışlayıcılığın bir bireysel davranış düzeyinde, 'yok sayma' ve 'ötekileştime' şeklinde tanımlandığı görülmektedir. Örneğin;

"Farklllikların kabul görmemesi ve benimsenmemesi, yok saylma.

"Dışlama; senden olmayanı yok saymak ötekileştirmek ve göz ardı etmek."

Örgütsel açıdan ise dışlama davranışının IK temelli kararlarda 'ayrımcılığa maruz bırakmak' ile ilişkilendirildiği görülmektedir. Bir katılımcı bu durumu şu şekilde ifade etmiştir;

"Beklenen özelliğe sahip olmayan kişinin ilgili durum/ortama dâhil edilmemesi...[örneğin]din ya da cinsiyet nedenli istihdam/terfi süreçleri olması"

İK yöneticilerinin cevaplarında literatürdeki tartışmalara paralel biçimde (Ferdman, 2017; Mor Barak; 2015), "hakim/baskın olanın tanımladığının dışında kalma" vurgusunun ifadelere yansıdığı gözlemlenmektedir. $\mathrm{Bu}$ vurgu bir katılımcının ifadelerinde açıkça görülmektedir;

"Çoğunluğun oluşturduğu yapının kendi yapısına uymayan farklıliğl enformel şekilde sistem dışına itmesidir. Dışlayıcı işletmenin en belirgin özelliği "bizden değil" mantığı ile hareket etmesi ve bunu tüm işlevsel alanlarına uygulamada nüfuz ettirmesidir."

$\mathrm{Bu}$ ifadeler incelendiğinde, tıpkı kapsayıcılık kavramı gibi dışlayıcılık kavramının da İK yöneticileri tarafından özüne oldukça yakın şekilde 
İnsan Kaynakları Yöneticilerinin Gözünden Çeşitlilik, Kapsayıcılık ve Dışlayıcılık

kavramsallaştırıldığı görülmektedir. Bu iki kavram ile ilgili olarak araştırma kapsamında katılımcılara yöneltilen diğer bir soru, kimlerin iş yaşamında daha çok dışlandığına dair düşüncelerini öğrenmek amacıyla "sizce, yukarıda saydı̆ğnız çeşitli/farklı gruplardan en çok hangisi/hangileri çalışma hayatından dışlanmaktadır?" şeklindedir. Bu soruya verilen cevaplarda etnik köken, siyasi yönelim, dini yönelim ve cinsel yönelim boyutlarının en çok vurgulanan boyutlar olduğu görülmüştür. Örnek cevaplar aşağıdaki gibidir;

"Özellikle dini farklılık, etnik köken, siyasi görüs farklılıkları ve cinsel yönelimde Türk şirketler çeşitlilikten yana değiller"

"Standart bir Türk işletmesini gerçekçi olarak düşünecek olursak, siyasi yönelim, cinsel yönelim ve dini yönelim"

"Gizlenemeyen cinsel yönelim"

"Kapalı kadınlar"

Türkiye'de çalışma hayatında en çok dışlanan gruplar ile ilgili olarak BUÇAD üyelerinin görüş ve gözlemleri de benzer grupları işaret etmektedir. Örneğin bir üye siyasi yönelim ile ilgili olarak görüşlerini şu şekilde dile getirmektedir;

"Belli bir siyasi görüsse sahip olanlar o siyası görüşe sahip olmayan insanlar çok da fazla kabullenmiyorlar. Yani aslında siyasi görü̈s ayrımcılık nedenlerinden bir tanesi. KOBI'lerde bu daha ön planda..."

Bir başka BUÇAD üyesi ise din boyutu ile ilgili mezhepler konusunu dile getirmekte ve Sunni-Alevi ayrımına dikkat çekmektedir. Katılımcının görüşleri şu şekildedir;

"Bir kadın çalışanımız saçının örgü şeklinden dolayı Alevi olarak etiketlenip diğerleri tarafindan bariz dışlanmıştı. Mezhepler de çok önemli aslında"

BUÇAD üyeleri tarafından dışlandığı/ayrımcıllğa uğradığı belirtilen bir diğer boyut ise etnik köken boyutudur. Bir BUÇAD üyesi gözlemini ve bu boyut ile ilgili dernek faaliyetlerini şu sözlerle açıklamaktadır;

“İ̧̧ dünyasında Türkiye’ye özgü etnik köken ile ilgili farklllıkları kucaklamak ile ilgili şirketlerin bir şey yaptı̆̆ını hiç duymadım. Dernek olarak bizim de gündemimizde değil.

Aynı BUÇAD üyesi aynı zamanda resmi olarak çeşitlilik projesi yürütülen bir çokuluslu şirketin İK müdürü olmasından hareketle kendi çalıştı̆̆ şirket bünyesindeki cinsel yönelim boyutuna ilişkin tutumu şu şekilde ifade etmektedir;

"Mavi yaka pozisyonu için biri başvurmuştu, hafif efeminen hareketleri vardl, anlaşıldı ki adam gey. Tamam, çeşitlilik projesi yürütüyoruz ama o kadar da geniş bakamıyoruz. Çünkü çalı̧̧acă̆ı yer erkek ă̆ırlıklı bir yer. Neticede almadık, alamadık. Ayrımcilık yapmış olduk mu evet olduk."

Araştırma kapsamında 'çeşitli/farklı gruplardan en çok hangisi/hangileri çalışma hayatından dışlanmaktadır' şeklinde yöneltilen ve yukarıda örnekleri verilen soruya cevaben, katılımcıların en çok vurguladıkları çeşitlilik boyutları; etnik köken, siyasi yönelim, dini yönelim ve cinsel yönelim boyutları olmuştur. Dışlayıcılık ile ilgili olarak en çok vurgulanan bu boyutlar, kapsanma/dışlanma durumuna ilişkin 
algıyı resmetmek ve bunun sebeplerini anlamak açısından da önem taşımaktadır. Devam eden bölümde bu konu üzerinde durulacaktır.

\section{C. Çeşitlilik, Kapsayııılık ve Dışlayıcılık Kavramsallaştırmalarının Arka Planı}

Yukarıdaki bulgular değerlendirildiğinde, araştırmaya katılan İK yöneticileri tarafından Türkiye'ye özgü çeşitlilikler olarak sayılan boyutların etnik köken, dini ve siyasi yönelim boyutları olduğu görülmektedir. Cinsel yönelim boyutuna genellikle çekinceli yaklaşıldığı ve görülmüş ve bu boyut katılımcılar tarafından en az dişe getirilen boyut olmuştur. Katılımcıların zihninde-özellikle yerli sermayeye ait şirketlerin İK yöneticilerin- çeşitlilik yönetimi ile ilgili net bir kavramsallaştırma olmadığı ancak sınırlı şekilde çeşitliliğin yönetilmesinin fursat eşitliği ile ilişkilendirildiği tespit edilmiştir. Bu kavramsallaştırma, ABD çıkışlı pratiğin özü ile örtüşmemektedir. Çeşitliliğin yönetimi kavramsallaştırmasındaki farklılaşmaya karşın, pratiğin kendi içinde ulaştığı son hal olarak kabul edilen kapsayıcılık kavramsallaştırması, kavramın özü ile paralellik taşımaktadır. Benzer şekilde kapsayıcılık ile birlikle ele alınan dışlayıcılık kavramsallaştırması da özgün haline oldukça yakındır. Bu noktada, kapsayıcılık ve dışlayıcılık ile ilgili İK yöneticilerinin zihninde net bir tanımlama olduğunu söylemek mümkündür. Ancak, 'Çalışma hayatında dışlanan gruplar var mı, varsa hangileri?' şeklinde yöneltilen soruya verilen cevaplar dikkat çekici bazı noktaları işaret etmektedir. Öyle ki, İK yöneticileri, çeşitlilik olarak tanımladıkları boyutların (etnik köken, siyasi yönelim, dini yönelim gibi) aslında Türkiye'de kapsayıcılık temelinde ele alınmadığını, hatta bu grupların çalışma hayatında ayrımcılığa uğradıklarını düşündüklerini belirtmektedirler. Bu durumun nedenine ilişkin sorgulamada alınan yanıtlarda birkaç nokta ön plana çıkmaktadır.

Katılımcılar tarafından vurgulanan ilk neden, Türkiye'ye özgü farklılık/çeşitliliklerin (ör.etnik köken, mezhepler) ABD bağlamında olduğu gibi ekonomik bir karşılıkla ilişkilendirilmemesi ve dolayısıyla da stratejik avantaj kaynağı olarak kabul edilmemesidir. Başka bir ifade ile bu çeşitliliği yönetmemekten kaynaklanan ekonomik bir kayıp ya da yetkinlikten yoksun kalma durumu yoktur. Bu kapsamda yapılan yorumlardan bazıları şu şekildedir;

"ABD'yi ayakta tutan şey ekonomi, diversity[çeşitlilik] de bunu destekliyor. Hispanikler, Asyalılar vb. oradaki dinamikler diversityi[çeşitliliği] destekliyor ayakta tutuyor ama bizde bu çok farkll. Ekonomik dinamikler farkl, toplumsal dinamikler farkll."

"Eğitim seviyesi ile de ilişsili, hem kapalı hem de benim ihtiyacım olan yetkinliklere, eğitime sahip aday sayısı çok fazla değil."

Bununla birlikte, Türkiye'ye özgü farklılıklar/çeşitlilikler olarak nitelendirilmelerine rağmen etnik köken, mezhepler gibi boyutların neden örgütlerin uygulamalarına yansımadığı sorgulandığında alınan cevaplar birkaç farklı noktayı işaret etmektedir. Üyeler ilk olarak son döneme hâkim olan makro politiğin 
İnsan Kaynakları Yöneticilerinin Gözünden Çeşitlilik, Kapsayıcılık ve Dışlayıcılık

işletmelere yansıdığını vurgulamaktadırlar. $\mathrm{Bu}$ kapsamda verilen cevaplardan bazıları şu şekildedir;

"Eskiden Türkiye'de çeşitlilik olayı içselleşmişti ve özümsenmişti. Biz sonradan ayrıştık, ayrıştırıldık ve maalesef bunun iş ortamına da yansıması oluyor. Dışlanan grupları çeşitlilik programlarına dâhil edemiyoruz, çekiniyoruz çünkü siyasi açıdan bir kutuplaşma var, toplumsal kabuller var"

"Tarihimizden süregelen bu çok çeşitli insan yaşamı her zaman barış, mutluluk içinde sürmüş̧ür. Fakat son zamanlarda kendisine göre farkll olan her insanı dışlayan bir toplum yapısına dönüş̧ük. Haliyle bu durum işletmelere de yansimaktadir."

Yukarıda ifade edilen makro politik etkinin, işletmelerin uygulamalarında "tehlikeli boyutlardan kaçınmak" şeklinde yansıdığı görülmektedir. Aşağıdaki ifadeler bu değerlendirmeyi destekler niteliktedir.

"Sadece bazı şirketler onlar da uluslararası gender [kadın-erkek] çeşitliliği ile ilgili faaliyetlerini raporluyorlar.... Diğerlerine bulaşmak istemiyorlar, o politik şeyden uzak durmak istiyorlar. Çünkü öyle yaparsanız bölücü derler. Dolayısıyla hiç bulaşmayalım noktasında duruyoruz biraz, bulaşmak istemiyoruz."

"Etnik kökeni yönetmesi zor ve onunla ilgili bir şey koymak ve yönetmeye kalkmak, ölçmek tehlikeli, buna gerek yok.”

Görüşmecilerin çeşitlilik boyutu olarak tanımlanmasına rağmen çeşitlilik yönetimi ve kapsayıcılık temelinde sessiz kalınan boyutlar ile ilgili dile getirdikleri diğer bir neden ise toplumsal normlar ve dinin etkisidir. Bu etki, en temel olarak toplumsal açıdan kabul edilirliği olmadığı gerekçesiyle cinsel yönelim boyutu ile ilgili vurgulanmaktadır. Bu konuda görüşmecilerin ifadeleri şu şekildedir;

"Şimdi Türkiye'de hangi şirkette adam ben geyim diye ortaya çıkar, hangi kadın ben lezbiyenim diye ortaya çıkar? Bu biraz insanlarla da ilgili, öyle bir ortam yok, toplumsal olarak kabul edilirliği yok. Bunun için herhalde Türkiye'de aşağı yukarı bir 100 yll falan gerekiyor."

"Yönetim olarak biz çeşitlilik projesi başlattık diyebiliyorsunuz ama görüntü farklılıklarından bile problem çıkabiliyor. Hele cinsel tercih ile ilgili konuda pek ümidim yok. Yani bizim bu noktaya gelmemiz... Isslam dininin içerisinde bunu çok mümkün görmüyorum ben."

Makro politik, dini ve toplumsal normların yanı sıra, görüşmeciler tarafından çeşitlilik ve kapsayıcılık uygulamalarına sınır getiren bir diğer etkenin "örgütsel normlar" olduğu görülmektedir. Bu durum şu şekilde dile getirilmiştir;

"Dini, etnik, cinsel ve siyasi farklılıklar daha iş görüşmesi sirasında şirketin kendini konumlandırdĭ̆ kimliğe bağlı olarak elenmesine ve sistem dışına itilmesine maruz biraklmaktadır."

$\mathrm{Bu}$ durum diğer bir insan kaynaklar yönetişinin ifadelerinde daha net ortaya çıkmaktadır. Öyle ki sosyal barışın bozulmaması adına belirli grupların dışlanması söz konusu olabilmektedir.

"Ben şirketimi biliyorum, ben insan kaynaklarıyım. Ben buraya başörtülü birisini alırsam, şirket içerisindeki sosyal barışa zarar veririm. Şirketin kültürünün 
bunu kabul etmeyeceğini ve sindirmeyeceğini düşünüyorum. Ben buraya öyle birisini alırsam o kişi de zarar görür, organizasyon da zarar görür"

$\mathrm{Bu}$ ifadeler literatürde dışlayıcı tutuma çerçeve çizdiği vurgulanan "ana akımdan farklı olma", "norm olarak belirlenenden sapma" şeklindeki tanımlamalarla (Mor Barak, 2015; Mor Barak ve Daya, 2014) örtüşmektedir. Bu noktada, cevaplayıcıların çalıştıkları işletmelerin ve çalışanların genel profilinin belirleyici olduğu açıktır. Öyle ki, başka bir örneklemin, farklı bir profili norm olarak kabul etmesi ve belki de kapalı kadınlar yerine açık kadınların dışlanması mümkün görünmektedir.

\section{Tartışma ve Sonuç}

Bu çalışmada, ortaya çıkışı itibariyle ABD'ye özgü (Kelly Dobbin, 1998; Wrench, 2007) ve bağlam bağımlı (Calas vd., 2009; Omonovic, 2009) olduğu kabul edilen çeşitlik yönetimi üzerinden, Türkiye gibi farkl1lıklar konusunda hassas kabul edilen bir ülkede, söz konusu pratiğe temel teşkil eden, çeşitlilik, kapsayıcılık, dışlama gibi kavramların "nasıl”" anlamlandırıldığı araştırılmıştır. Daha açık bir ifade ile Türkiye bağlamında bu kavramlarının ne şekilde tanımlandığı; çeşitlilik dendiğinde hangi boyutların algılandığı, hangi boyutların çeşitlilik yönetimi ve kapsayıcılık temelinde ele alındığı, hangilerinin kapsam dışı bırakıldığı ve bu tercihin arkasındaki nedenlerin neler olduğu tespit edilmeye çalışılmıştır.

Araştırma kapsamında elde edilen veriler, Türkiye'de farklılık/çeşitlilik dendiğinde en çok dile getirilen çeşitlilik boyutların "etnik köken" ve "mezhepsel" farkl1lıklar olduğunu göstermektedir. Bununla birlikte, siyasi yönelim de sık dile getirilen boyutlar arasındadır. Cinsiyet boyutu üzerinden ise "evli-dul" ve "kapal1açık" kadınlar şeklinde tanımlamaların yapıldığı görülmektedir. Engellilik boyutu da cevaplayıcılar tarafından sık dile getirilmiştir. Katılımcılar tarafından en az dile getirilen boyut ise "cinsel yönelim" boyutu olmuştur.

Özellikle yerli sermaye ait işletmelerdeki IK yöneticilerinin zihninde çeşitlilik yönetimine ilişkin net bir kavramsallaştırma olmadığı görülürken, sınırlı sayıda İK yöneticisinin ise çeşitlilik yönetimini fursat eşitliği ile özdeşleştirdikleri görülmektedir. $\mathrm{Bu}$ ilişkilendirme çeşitlilik yönetiminin özünü oluşturan "çeşitliliklerden stratejik avantaj elde etme" anlayışından (Cox ve Blake, 1991; Kelly ve Dobbin, 1998; Thomas, 1990;1991) farklı bir kurguyu işaret etmektedir. Bununla birlikte, literatürde çeşitlilik yönetimi anlayışının kapsayıcılık anlayışına doğru evirildiğini vurgulayan çalışmaları referans alarak (ör. Oswik ve Noon, 2014), kapsayıcılık ve dışlayıcılık kavramları üzerinden, Türkiye bağlamında hangi grupların iş yaşamında daha çok dışlanma eğiliminde oldukları sorgulandığında; cevaplayıcıların çoğunluğu etnik köken (ör. Kürt) ve mezhepleri (ör. Alevi) dile getirmektedirler. Bu bulgu, cevaplayıcıların Türkiye'ye özgü olarak tanımladıkları çeşitlilik boyutlarıyla birebir örtüşmektedir. Bununla birlikte siyasi yönelim, cinsel yönelim, cinsiyet (kapalı-açık kadınlar) da dışlanan çeşitlilik boyutları arasında sıklıkla sayılmaktadır. 
İnsan Kaynakları Yöneticilerinin Gözünden Çeşitlilik, Kapsayıcılık ve Dışlayıcılık

Kapsayıcılı̆̆ın, "farklı kabul edilerek ayrımcılığa uğrayan grupların üyelerine, örgütlerin tüm süreçlerine katılma ve katkıda bulunmalarına imkan vermek" şeklinde (Ferdman, 2014; Shore vd., 2018) tanımlandığı hatırlandığında, IK yöneticileri tarafından bağlama özgü çeşitlilikler/farklılıklar olarak algılanıyor olmalarına ve kendilerinin de kapsayıcılığı benzer kelimelerle ifade etmiş olmalarına rağmen, bu grupların kapsayıcılık temelinde ele alınmıyor olmaları ilginçtir. Buradan hareketle, cevaplayıcıların zihninde bağlama özgü çeşitlilikler ve dışlanan gruplar netken, kapsayıcılık ile ilgili kavramsallaştırma -çeşitlilik yönetiminden farklı olarak- özüne oldukça yakınken, söz konusu grupların "neden" bu temelde ele alınmadıklarına ilişkin bir çözümleme, yerel bağlamda tüm bu kavramların nasıl (yeniden) inşa edildiğine 1şı tutabilecektir.

Bu noktada, çeşitlilik yönetimi ve kapsayıcılık/dışlayıcılık uygulamalarının, taşıdıkları toplumsal, kültürel, siyasi yükler ve bağlam bağımlığı niteliği nedeniyle, bir meşruiyet sorgulamasına tabi olduğu açıktır. Öyle ki bu durum, meşru ve meşru olmayan çeşitlilik arasında ne şekilde bir ayrım yapıldığı, çeşitlilik ve kapsayıcılık söyleminin nasıl şekillendiği ve çeşitliliğin nasıl ele alındığı hakkında bir anlayış geliştirilmesine imkân vermektedir. Dobush (2017:1648)'un ifadesi ile "olası sorunları önleyecek şekilde yalnızca 'pazarlanabilir' farklılıklar $\mathrm{ml}$ dile getirilmektedir, yoksa 'marjinal' kabul edilen gruplar ve sosyal eşitsizlikler de işaret edilmekte midir?". Aslında böyle bir sorgulama, ilgili söylemin oluşmasını ve fiili olarak ifade edilmesini sağlayan belirli "koşulları", başka bir deyişle; belirli bir bağlamda "söylenebilir" olan ve bu nedenle "yapılabilir" olarak algılananları (Dobush, 2017,s.1649) ortaya çıkarmaya da olanak tanımaktadır. Öyle ki, bu bağlamsal koşullar çeşitlilik söyleminin sınırlarını belirleyebilmekte; kapsayıcı ya da dışlayıcı uygulamalara çerçeve çizmektedir. Her ne kadar özellikle büyük ve yabancı sermayeli işletmelerin İK yöneticilerinin söyleminde pragmatik bir etkinlik arayışı izlense de çeşitlilik/kapsayıcılık/dışlayıcılık kavramlarından ne anlaşıldığını ve işletmelerin bu alanda nasıl davrandığını belirleyen gücün, kurumsal bağlamda şekillenen meşruiyet algısı olduğunu söylemek mümkün görünmektedir. Tam bu noktada, bir BUÇAD üyesi tarafından dile getirilen ifadeye tekrar yer vermek uygun olacaktır;

"Dışlanan grupları çeşitlilik programlarına dâhil edemiyoruz, çekiniyoruz çünkü siyasi açıdan bir kutuplaşma var, toplumsal kabuller var"

Tüm bunlar değerlendirildiğinde, Türkiye bağlamında, çeşitlilik ve kapsayıcılık ile ilgili "meşru" kabul edilenlerin ve dolayısıyla "söylenebilir" ve "yapılabilir" olanların, bağlamın kendine özgü tarihi, siyasi, dini ve sosyo-kültürel yükleri nedeniyle oldukça sinırlı olduğunu söylemek mümkün görünmektedir. Türkiye'ye özgü bu tablo, ilgili literatürdeki 'çeşitlilik ve kapsayıcıllk kavramlarının çeşitli çatışmaları ve gerginlikleri barındırdığı' vurgusunu (Ferdman, 2017) haklı çıkarmaktadır. Belki de Türkiye bağlamında, bu çatışma ve gerginliklerden kaçınmak için sadece belirli gruplar çeşitlilik ve kapsayıcılık söylemine dâhil edilmektedir. Böylesi bir kapsayıcılık anlayışı, Ferdman (2018:100) tarafindan "şartlı kapsayıcılık" şeklinde nitelendirilen ve aslında çeşitliliğe izin vermeyen, 
çeşitliliği cesaretlendirmeyen ve kolaylaştırmayan "sözde" bir kapsayıcılık anlayışı ile de örtüşüyor görünmektedir.

\section{Kaynaklar}

Acar Erdur, D. ve Sayllar, Y. (2017). Expansion of the non-legitimate: diversity management in Turkey.' 33. EGOS Colluquium, The Good Organization, Aspirations, Interventions, Struggles, 6-8 July, Copenhag, Denmark.

Ahonen, P., Tienari, J., Meriläinen, S. ve Pullen, A. (2014). Hidden contexts and invisible power relations: A Foucauldian reading of diversity research. Human Relations, 67(3), 263-286.

Barbosa, I. ve Cabral-Cardoso, C. (2010). Equality and diversity rhetoric: one size fits all? Globalization and the Portuguese context. Equality, Diversity and Inclusion: An International Journal, 29(1),97-112.

Bell, M. P., Özbilgin, M. F., Beauregard, T. A. and Sürgevil, O. (2011). Voice, silence, and diversity in 21st century organizations: Strategies for inclusion of gay, lesbian, bisexual, and transgender employees. Human Resource Management, (50), 131-146.

Boxenbaum, E. (2006). Lost in translation: the making of danish diversity management. American Behavioral Scientist, (49), 939-48.

Calas, M.B., Holgersson, C. and Smircich,L. (2009). "Diversity management"? translation? travel?.Scandinavian Journal of Management, 25(4),349-351.

Cox, T. H. ve Blake, S.(1991). Managing Cultural diversity: implications for organizational competitiveness. The Executive, 5(3), 45-56.

Dobusch, L. (2017), Diversity Discourses and the articulation of discrimination: the case of public organisations. Journal of Ethnic and Migration Studies, 43(10),1644-1661.

Downey, S. N., van der Werff, L., Thomas, K. M., ve Plaut, V. C. (2015). The role of diversity practices and inclusion in promoting trust and employee engagement. Journal of Applied Social Psychology, 45(1), 35-44.

Ferdman, B. M. (2017). Paradoxes of Inclusion: Understanding and Managing the Tensions of Diversity and Multiculturalism. The Journal of Applied Behavioral Science, 53(2), 235-263

Ferdman, B. M. (2018). In Trump's shadow: questioning and testing the boundaries of inclusion. Equality, Diversity and Inclusion: An International Journal, 37 (1),96-107.

Ferdman, B. M. (2014). Toward infusing diversity and inclusion as core elements of od. OD Practitioner, 46 (4): 44-46.

Ferner, A., Almond, P. ve Colling, T. (2005). Institutional theory and the crossnational transfer of employment policy: the case of 'workforce diversity' in US multinationals. Journal of International Business Studies, 36(3), 304-321.

Heres, L. ve Benschop Y., (2010). Taming diversity: an exploratory study on the travel of a management fashion. Equality, Diversity and Inclusion: An International Journal, 29(5), 436-457. 
İnsan Kaynakları Yöneticilerinin Gözünden Çeşitlilik, Kapsayıcılık ve Dışlayıcılık

Janssens, M. ve Zanoni, P. (2008).What makes an organization inclusive? Organizational practices favouring the relational inclusion of ethnic minorities in operative jobs", presented at the 21st IACM Conference, Chicago, IL, 3-6 July.

Kelly, E. ve Dobbin, F. (1998). How affirmative action became diversity management. The American Behavioral Scientist, 41(7),960-984.

Klarsfeld, A. (2009). The diffusion of diversity management : the case of France. Scandinavian Journal of Management, 25(4), 363-373.

Kuş,E. (2003). Nicel-Nitel Araştırma Teknikleri, Sosyal Bilimlerde Araştırma Teknikleri: Nicel mi? Nitel mi', Anı Yayınc1lı, Ankara.

Lauring J., (2009). Managing cultural diversity and the process of knowledge sharing: a case from Denmark. Scandinavian Journal of Management, 25(4),385-394.

Meriläinen, S., Tienari, J., Katila, S. and Benschop, Y. (2009). "Diversity management versus gender equality: the Finnish Case. Canadian Journal of Administrative Sciences, 26(3), 230-243.

Mor Barak, M.E. (2015). Inclusion is the key to diversity management, but what is inclusion? Human Service Organizations Management, Leadership \& Governance, 39(2), 83-88.

Mor Barak, M. E. ve Daya, P. (2014). Fostering inclusion from the inside out to create an inclusive workplace". In B. M. Ferdman, \& B. R. Deane (Eds.), Diversity at work:The practice of inclusion (391-412). San Francisco, CA: Jossey-Bass.

Nishii. L. H. (2013). "The benefits of climate for inclusion for gender-diverse groups", Academy of Management Journal, Cilt 56, 1754-1774.

Nishii, L. H., ve Rich, R. E. (2014). Creating inclusive climates in diverse organizations. In B. M. Ferdman, ve B. R. Deane (Eds.), Diversity at work: The practice of inclusion (205-228). San Francisco, CA: Jossey-Bass.

Offerman, L. R.. ve Basford, T. E. (2014). Best practices and the changing role of human resources. In B. M. Ferdman, \& B. R. Deane (Eds.), Diversity at work: The practice of inclusion (229-259). San Francisco, CA: Jossey-Bass.

Omanovic,V.,(2009). Diversity and its management as a dialectical process:Encountering Sweden and the U.S. Scandinavian Journal of Management, 25(4), 352-362.

Oswick, C. and Noon, M. (2014). Discourses of diversity, equality and inclusion: trenchant formulations or transient fashions? British Journal of Management, 25(1), 23-39.

Özen, Ş. (2002). Toplam kalite yönetiminin Türkiye'de yeniden kurgulanması: Koşul bağımlı türdeşleşme tezinin bir testi. Amme İdaresi Dergisi, 35(1), 10542.

Özen, Ş. (2017). Çok bölümlü yapı Türkiye'ye gelince nasıl holding'e dönüştü? Yerel ve ithal yönetim uygulamalarının merkez ve çevre ülkelerde 
meşrulaştırılması. Yönetim ve Çalışma Dergisi / Journal of Management and Labour, 1(1),2-22.

Risberg, A. ve Soderberg, A.M. (2008). Translating a management concept: diversity management in Denmark. Gender in Management: An International Journal, 23,426- 441 .

Roberson, Q. M. (2004). Disentangling the meanings of diversity and inclusion (CAHRS Working Paper \#04-05)", Ithaca, NY: Cornell University, School of Industrial and Labor Relations, Center for Advanced, Human Resource Studies.

Sabharwal, M. (2014). Is diversity management sufficient? Organizational inclusion to further performance. Public Personnel Management, 43(2), 197-217.

Shore, L.M, Cleveland, J.N. and Sanchez, D. (2018). Inclusive workplaces: a review and model, Human Resource Management Review, 28(2), 176-189.

Sippola, A.ve Smale, A. (2007). The global integration of diversity management: A longitudinal case study. The International Journal of Human Resource Management, 18(11),1895-1916.

Syed, J., ve Özbilgin, M. (2009), A relational framework for international transfer of diversity management practices. International Journal of Human Resource Management, 20(12), 2435-2453

Tang, N., Jiang, Y., Chen, C., Zhou, Z., Chen, C. C. ve Yu, Z. (2015). Inclusion and inclusion management in the Chinese context: An exploratory study. The International Journal of Human Resource Management, 26(6), 856-874.

Thomas RR. (1990). From affirmative action to affirming diversity. Harvard Business Review 68(2), 107-117.

Thomas, R.R. (1991). Beyond race and gender: unlashing the power of your total work force by managing diversity. New York: American Management Association.

Wrench, J.,(2007). Diversity management and discrimination: immigrants and ethnic minorities in the EU', Ashgate, Aldershot.

Yıldırım, A. ve Şimşek,H. (2000). Sosyal Bilimlerde Nitel Araştırma Yöntemleri. Seçkin Yayıncılık, Ankara.

Zanoni, P., Janssens, M., Benschop, Y., ve Nkomo, S. (2010). Guest Editorial: Unpacking Diversity, Grasping Inequality: Rethinking Difference Through Critical Perspectives. Organization, 17(1), 9-29. 